\title{
IDENTIFIKASI KEANEKARAGAMAN JENIS BURUNG DAN KEARIFAN TRADISIONAL MASYARAKAT DALAM UPAYA KONSERVASI DI PULAU RAMBUT KEPULAUAN SERIBU
}

\author{
MASHUDI A. \\ mashudi.alamsyah@gmail.com \\ GIRY MARHENTO \\ girymarhento@gmail.com

\begin{abstract}
Program Studi Pendidikan Biologi, Fakultas Teknik, Matematika dan IPA Universitas Indraprasta PGRI Jakarta
\end{abstract}

\begin{abstract}
Abstrak. Tujuan penelitian ini adalah untuk: (1) Menganalisis keanekaragaman jenis burung di Pulau Rambut Kepulauan Seribu menggunakan metode encounter rates (tingkat pertemuan) yaitu pengamatan langsung dengan cara menjelajah dan menghitung setiap individu yang ditemui, (2) Menjelaskan bentuk kearifan tradisional masyarakat Pulau Untung Jawa Kepulauan Seribu, dan (3) Menjelaskan ancaman terhadap kearifan serta menganalisis cara menangkal ancaman dalam upaya melestarikan burung. Pencarian data menggunakan observasi langsung berupa eksplorasi dan wawancara pada narasumber yang dapat dipercaya. Pengamatan dilakukan dengan teropong binokuler merk carton dengan ukuran 8 × 30 tipe 430 FT/1000 YDS made in Japan. Setiap burung yang dijumpai diperhatikan ukuran, warna, dan suaranya sera ciriciri khasnya, kemudian diidentifikasi. Masyarakat Pulau Untung Jawa menganggap burung yang ada di Pulau Rambut merupakan anugerah dan berkah yang harus dilestarikan. Keanekaragaman jenis burung di Pulau Rambut Kepulauan Seribu cukup tinggi yaitu ditunjukkan dengan 24 jenis burung. Adanya aktivitas masyarakat Pulau Untung Jawa diduga memberikan pengaruh terhadap keanekaragaman jenis burung yang terdapat di Pulau rambut Kepulauan Seribu.
\end{abstract}

Kata Kunci: Identifikasi Keanekaragaman, Jenis Burung, Kearifan Tradisional, Pulau Rambut, Kepulauan Seribu.

\section{PENDAHULUAN}

Indonesia merupakan salah satu negara prioritas utama dalam upaya pelestarian keanekaragaman hayati karena memiliki biodiversity yang paling besar di dunia. Ancaman utama terhadap keanekaragaman hayati adalah rusaknya atau hilangnya habitat, dan cara yang paling baik untuk melindungi keanekaragaman hayati adalah dengan menjaga dan memelihara habitat. Pada masa ini kerusakan habitat umumnya merupakan akibat dari pemenuhan kebutuhan hidup manusia. Berbagai program telah dijalankan pemerintah untuk melakukan konservasi baik secara insitu maupun exsitu akan tetapi kenyataan menunjukkan bahwa populasi burung semakin berkurang. Kepentingan manusia yang berkaitan dengan alam juga seringkali menimbulkan adanya budaya yang mampu mempertahankan kelestarian alam itu sendiri. Keberadaan spesies kunci yang bernilai budaya tidak jarang memberikan pengaruh yang baik terhadap konservasi jenis yang bersangkutan (Garibaldi and Turner, 2004: 87).

Salah satu pulau yang ada di bawah pengawasan Balai Taman Nasional Laut Kepulauan Seribu (BTNLKpS) adalah Pulau Rambut, yang juga dikenal sebagai "surga burung laut". Luas pulau ini sekitar 90 hektar, 45 hektar di antaranya adalah daratan. Pulau yang sejak 1999 ditetapkan sebagai kawasan suaka margasatwa ini memiliki 
keanekaragaman hayati yang luar biasa, baik flora maupun fauna. Pulau Rambut pertama kali diusulkan penetapannya sebagai kawasan konservasi oleh Direktur Kebun Raya Bogor kepada Gubernur Jenderal Hindia Belanda Jakarta dengan status berupa cagar alam. Alasan penting yang mendasari usulan tersebut adalah untuk melindungi berbagai jenis burung air yang banyak terdapat di pulau tersebut.

Secara resmi, Pulau Rambut ditetapkan sebagai cagar alam pada 1937 melalui Surat Keputusan Gubernur Jenderal Hindia Belanda No. 7 tanggal 3 Mei 1937. Selanjutnya keputusan tersebut dimuat dalam Lembar Negara (Staatblat) No. 245 Tahun 1939. Sedangkan pelaksanaannya diatur dalam Peraturan (Ordonansi) Perlindungan Alam tahun 1941 yang dimuat dalam Lembar Negara No. 167 tahun 1941. Pada saat itu, Pulau Rambut dinyatakan seluas 20 hektar. Berdasarkan pertimbangan tersebut, Pulau Rambut ditetapkan sebagai Suaka Margasatwa oleh Menteri Kehutanan dan Perkebunan melalui Surat Keputusan Nomor 275/Kpts-II/1999 tanggal 7 Mei 1999 seluas 90 hektar, yang terdiri dari 45 hektar daratan dan 45 hektar perairan.

Secara geografis, kawasan Suaka Margasatwa Pulau Rambut terletak di antara $106^{\circ} 41^{\prime} 14^{\prime \prime}$ - $106^{\circ} 41^{\prime} 46^{\prime \prime}$ BT dan 5 56'47" - 5 $5^{0} 56^{\prime} 57^{\prime \prime}$ LS, yaitu ke arah barat laut dari Pelabuhan Tanjung Priok. Sedangkan menurut administrasi pemerintah, Pulau Rambut termasuk wilayah Kelurahan Pulau Untung Jawa, Kecamatan Kepulauan Seribu Selatan, Kabupaten Administrasi Kepulauan Seribu.

Sebagian besar fauna penghuni Pulau Rambut adalah burung, sekitar 22 jenis burung merandai (burung air) dan 39 jenis burung darat. Sebagian besar burung air atau burung laut adalah burung penetap yang menghuni Pulau Rambut sepanjang tahun. Yang menarik, burung-burung ini memiliki perilaku migrasi ke Pulau Jawa atau pulau lain di Kepulauan Seribu untuk mencari makan pada pagi hari dan kembali ke Pulau Rambut pada sore hari untuk beristirahat. (BTNLKpS, 2010).

Pulau lain yang dekat dengan Pulau Rambut adalah Pulau Untung Jawa. Penduduk pulau ini menyediakan penginapan bagi pengunjung yang ingin menuju ke Pulau Rambut, berjarak kurang dari $2 \mathrm{Km}$ dari Pulau Rambut, Pulau Untung Jawa merupakan zona penyangga konservasi. Kearifan tradisional masyarakat sekitar sangat berpengaruh terhadap aktifitas keanekaragaman jenis flora dan fauna yang ada di Pulau Rambut. Dalam pengelolaan Suaka Margasatwa Pulau Rambut, Pulau Untug Jawa telah ditetapkan sebagai daerah penyangga (buffer zone) untuk menunjang kegiatan pengawasan dan pengamanan kawasan tersebut. Masyarakat turut berpartisipasi dalam kegiatan pembangunan di Pulau Rambut, serta dengan menginformasikan potensi Pulau Rambut kepada wisatawan yang datang.

Tingkat ketergantungan masyarakat adat yang tinggi terhadap sumberdaya alam akan memiliki pengaruh yang besar terhadap kondisi alam salah satunya keanekaragaman burung serta kondisi sosial budaya masyarakat itu sendiri. Sehubungan dengan perkembangan eksploitasi fauna dan flora secara besar-besaran akan mengubah kearifan dalam pemanfaatan burung. Berdasarkan permasalahan tersebut di atas, maka tujuan penulisan ini adalah untuk menganalisis keanekaragaman jenis burung di Pulau Rambut Kepulauan Seribu, menjelaskan bentuk kearifan tradisional masyarakat Pulau Untung Jawa Kepulauan Seribu dan menjelaskan ancaman terhadap kearifan serta menganalisis cara menangkal ancaman dalam upaya melestarikan burung.

\section{METODE}

Penelitian ini dilakukan dengan sistem encounter rates (tingkat pertemuan) dengan menjelajahi dan menghitung setiap burung yang dijumpai di Pulau Rambut Kepulauan Seribu. Penelitian dilakukan pada pagi hari dari pukul 06.00-09.00 dan sore hari pukul 15.30-17.30 selama 3 kali pengulangan pada bulan Maret 2016. Pengamatan 
dilakukan oleh 5 kelompok pengamat yang masing-masing menjelajah daerah yang berbeda disesuaikan dengan kondisi di Pulau Rambut Kepulauan Seribu. (Balen Van B, 1999: 105).

Pengamatan dilakukan dengan teropong binokuler merk carton dengan ukuran $8 \mathrm{x}$ 30 tipe 430 FT/1000 YDS made in Japan. Setiap burung yang dijumpai diperhatikan ukuran, warna, dan suaranya sera ciri-ciri khasnya, kemudian diidentifikasi dengan buku Mac Kinnon (1991), dan Mac Kinnon, dkk. (1998). Secara kualitatif struktur vegetasi habitat burung diidentifikasi dengan buku Botanica (1998) dan buku-buku lain yang diperlukan. Pencatatan data meliputi; jenis burung, jumlah burung, habitat, aktivitas. Untuk menentukan kelimpahan relatif dengan menghitung tingkat pertemuan setiap jenis dengan membagi jumlah burung yang tercatat dengan jumlah jam pengamatan, yang memberikan hasil jumlah burung perjam untuk setiap jenis.

Kemelimpahan Relatif = Jumlah Individu tiap Jenis Burung

$$
\text { Jumlah Jam Pengamatan }
$$

Data yang di dapat ditabulasikan dalam skala urutan kemelimpahan sederhana dari Lowen dkk. (Collin Bibby, 2000).

Tabel 1. Penggunaan Tingkat Pertemuan Untuk Memperlihatkan Skala Urutan Kelimpahan Sederhana Dari Lowen Dkk. (Colin Bibby, 2000).

\begin{tabular}{ccc}
\hline $\begin{array}{c}\text { Kategori kelimpahan (jumlah } \\
\text { individu per 100 jam } \\
\text { pengamatan) }\end{array}$ & Nilai kelimpahan & Skala urutan \\
\hline$<\mathbf{0 , 1}$ & 1 & Jarang \\
$\mathbf{0 , 1}-\mathbf{2 , 0}$ & 2 & Tidak Umum \\
$\mathbf{2 , 1}-\mathbf{1 0 , 0}$ & 3 & Sering \\
$\mathbf{1 0 , 1 - \mathbf { 4 0 , 0 }}$ & 4 & Umum \\
$\mathbf{4 0 , 0 +}$ & 5 & Melipah \\
\hline
\end{tabular}

\section{HASIL DAN PEMBAHASAN}

Penelitian yang telah dilaksanakan pada bulan Maret 2016, dengan total pengamatan selama 75 jam didapatkan hasil sebagai berikut:

Tabel 2. Keanekaragaman spesies burung yang ditemukan di Pulau Rambut

\begin{tabular}{clcc}
\hline No & & $\begin{array}{c}\text { Jumlah } \\
\text { Individu/ } \\
10 \text { jam }\end{array}$ & $\begin{array}{c}\text { Skala } \\
\text { Urutan }\end{array}$ \\
\hline 1 & Cagak Merah (Ardea purpurea) & 30,2 & Umum \\
2 & Cagak Abu (Ardea cinerea) & 2,8 & Sering \\
3 & Kuntul Besar (Egretta alba) & 234,2 & Melimpah \\
4 & Kuntul Kecil (Egretta garzetta) & 93,3 & Melimpah \\
5 & Kuntul Karang (Egretta sacra) & 126,5 & Melimpah \\
6 & Bluwok (Mycteria cinerea) & 55,26 & Melimpah \\
7 & Roko-Roko (Plegadis falcinellus) & 40,5 & Melimpah \\
8 & Pecuk Ular (Anhinga melanogaster) & 10,4 & Umum \\
9 & Kuntul Sedang (Egretta intermedia) & 10,3 & Umum \\
10 & Kuntul Kerbau (Bubulcus ibis) & 0,5 & Tidak Umum \\
11 & Jalak Kerbau (Acridotheres javanicus) & 2,3 & Sering \\
12 & Walet Linchi (Collocalia linchi) & 2,7 & Sering \\
13 & Elang Laut Perut Putih (Haliaeetus Leucogaster) & 2,1 & Sering \\
\hline
\end{tabular}




\begin{tabular}{llcc}
\hline 14 & Pergam Laut (Ducula bicolor) & 90,65 & Melimpah \\
15 & Tekukur (Streptopelia chinensis) & 2,55 & Sering \\
16 & Asian Koel (Eudynamys scolopacea) & 1,83 & Tidak Umum \\
17 & Raja Udang Biru (Alcedo coerulescens) & 0,25 & Tidak Umum \\
18 & Cekakak Sungai (Todirhamphus chloris) & 0,43 & Tidak Umum \\
19 & Kepudang Kuduk hitam (Oriolus chinensis) & 1,75 & Tidak Umum \\
20 & Kucica Kampung (Copsychus saularis) & 230 & Melimpah \\
21 & Kekep Babi (Artamus leucorhynchus) & 10,2 & Umum \\
22 & Madu Kelapa (Anthreptes malaccensis) & 10,7 & Umum \\
23 & Madu Sriganti (Nectarinia jugularis) & 108 & Melimpah \\
24 & Emprit (Lonchura punctata) & 10,5 & Umum \\
\hline
\end{tabular}

Data mengenai kearifan tradisional masyarakat Pulau Untung Jawa diambil dengan cara wawancara, yaitu dengan cara mengunjungi secara langsung orang-orang yang dituakan (Lurah, Ketua Adat dan Ketua RT) dan anggota masyarakat yang dianggap mengetahui kondisi sosial budaya masyarakat (informan). Jumlah responden yang diwawancarai sebanyak 30 orang dengan umur diatas 25 tahun dari dua tempat yang berada di wilayah utara dan selatan (Tabel 3). Wawancara dilaksanakan pada sore hari (pukul 15.00-17.00 WIB) dan malam hari (pukul 20.00-22.00 WIB), dengan cara semi terstruktur.

Tabel 3. Rincian Jumlah Responden Menurut Umur, Jenis Kelamin dan Jabatan/Status dalam Masyarakat

\begin{tabular}{lcccccccc}
\hline Lokasi & \multicolumn{3}{c}{ Umur (Tahun) } & \multicolumn{3}{c}{ Jenis Kelamin } & \multicolumn{4}{c}{ Jabatan (Status) } \\
\cline { 2 - 9 } & $25-35$ & $>35$ & L & P & Lurah & Kepala & Ketua & $\begin{array}{c}\text { Lain- } \\
\text { lain }\end{array}$ \\
Utara & 15 & 7 & 16 & 6 & 0 & 1 & 1 & 20 \\
Selatan & 5 & 3 & 6 & 2 & 1 & 0 & 0 & 7 \\
Total & 20 & 10 & 22 & 8 & 1 & 1 & 1 & 27 \\
\hline
\end{tabular}

\section{Kearifan Tradisional Masyarakat Pulau Untung Jawa Kepulauan Seribu}

Masyarakat Pulau Untung Jawa mewujudkan kepercayaannya bahwa dengan menjaga kelestarian di lingkungan sekitar maka lingkungan sekitarpun akan ikut menjaga mereka. Mereka menganggap bahwa lingkungan melambangkan kegagahan, kemakmuran, kejayaan dan alat komunikasi dengan para leluhur. Selain lingkungan sekitar, terdapat pula burung-burung penanda yang apabila terdengar suaranya satu kali menandakan musibah, sedangkan lebih dari dua kali menandakan kesenangan dan berguna saat mereka bepergian.

\section{Ancaman Terhadap Kearifan dan Cara Menangkalnya}

Ancaman terbesar yang paling mengancam kearifan tradisional masyarakat Pulau Untung Jawa terhadap kekayaan burung di alam adalah keadaan ekonomi masyarakat. Hal ini dipacu oleh kebiasaan atau mata pencaharian masyarakat Pulau Untung Jawa yang menggantungkan sebagian hidupnya pada alam. Keadaan masyarakat masyarakat Pulau Untung Jawa saat ini mengalami kemunduran akibat tekanan masyarakat luar yang melakukan eksplorasi liar sehingga menghilangkan mata pencaharian masyarakat Pulau Untung Jawa selama ini dijadikan pegangan hidup mereka. Selain itu masyarakat Pulau Untung Jawa mengandalkan mata pencarian dengan mencari ikan sebagai nelayan dan membuka pariwisata yang menguntungkan bagi mereka. 
Sering terlihatnya para pemburu burung dari luar kawasan diduga akan menimbulkan minat berburu yang serupa pada masyarakat masyarakat Pulau Untung Jawa. Adanya desakan ekonomi dan tekanan serta pengaruh masyarakat luar akan mengubah mata pencaharian utama masyarakat Pulau Untung Jawa. Kenyataan seperti itu akan menyebabkan keanekaragaman jenis burung di Pulau Rambut terancam dan cenderung menurun.

Keanekaragaman jenis burung di Pulau Rambut akan terjaga apabila kearifan masyarakat Pulau Untung Jawa terhadap alam tetap dipertahankan, terutama menjaga kekayaan jenis burung dan dapat dilestarikan. Oleh karenanya, pihak pengelola BTNLKpS perlu mengikutsertakan masyarakat Pulau Untung Jawa dalam seluruh kegiatan yang berhubungan dengan pelestarian alam guna memelihara lingkungan terutama keanekaragaman jenis burung yang ada di Pulau Rambut. Selain itu juga perlu diadakan penyuluhan maupun lokakarya yang mengingatkan bahwa kehidupan manusia tidak akan lepas dari alam.

\section{PENUTUP}

\section{Simpulan}

Keanekaragaman jenis burung di Pulau Rambut Kepulauan Seribu cukup tinggi yaitu ditunjukkan dengan 24 jenis burung. Adanya aktivitas masyarakat Pulau Untung Jawa diduga memberikan pengaruh terhadap keanekaragaman jenis burung yang terdapat di Pulau rambut Kepulauan Seribu. Ancaman terbesar dalam kehidupan arif masyarakat masyarakat Pulau Untung Jawa adalah ekonomi. Oleh karenanya dibutuhkan peran pengelola BTNLKpS untuk mengikutsertakan masyarakat Pulau Untung Jawa dalam seluruh kegiatan terutama dalam menjaga kelestarian dan keanekaragaman jenis burung yang terdapat di Pulau Rambut Kepulauan Seribu.

\section{Saran}

a. Perlunya penelitian lebih lanjut untuk menghitung kelimpahan absolut atau populasi mutlak dari masing-masing jenis yang ditemukan.

b. Di dalam penghijaun yang dilakukan perlu dipilih tanaman yang mendukung untuk pelestarian kehidupan berbagai jenis burung yang terdapat di Pulau Rambut Kepulauan Seribu.

c. Perlunya ada himbauan kepada masyarakat Pulau Untung Jawa agar tidak melakukan perburuan terhadap berbagai jenis burung yang terdapat di Pulau Rambut Kepulauan Seribu.

\section{DAFTAR PUSTAKA}

Balen, van B. 1984. Bird Counts And Bird Observation in The Neighbourhood of Bogor. Nature Conservation Dept. Agriculture University Wageningan.Wageningen The Netherlands: Bibby Press.

BTNKP. 2010. Makna dan Kekuatan Simbol Adat Pada Masyarakat Pulau Seribu: Di Kepulauan Seribu Ditinjau Dari Pengelompokan Budaya. Pulau 1000 Press.

Collin Bibby. 2000. Teknik-Teknik Survei Burung. Birdlife International Indonesia.

Garibaldi and Turner. 2004. Expedition Field Techniques Birds Surveys Expedition Advisor Centre. London: UK.HIMAKOVA.

John Mac Kinnon, Karen phillips, bas Van balen. 1998. Burung-burung di sumatra, Jawa, bali, dan Kalimantan. Puslitbang Biologi - LIPI.

John mac Kinnon. 1991. Panduan Lapangan Pengenalan Burung-Burung Di Jawa

Dan Bali.Yogyakarta: Gadjah Mada University Press. 
Laporan Kegiatan Studi Konservasi Lingkungan[SURILI]: Eksplorasi Ilmiah Keanekaragaman Hayati Satwa Indikator Kesehatan Lingkungan Hutan dan Tumbuhan di Taman Nasional Bukit Barisan Selatan, Lampung.

Putussibau.Wisnubudi, G. 2004. Keanekaragaman Dan Kelimpahan Jenis Avifauna Untuk Pengembangan Ekowisata Birdwatching di Taman Nasional Gunung Halimun Jawa Barat. Tesis tidak dipublikasikan. Sekolah Pascasarjana Institut Pertanian Bogor, Bogor.

Rencana Pengelolaan Taman Nasional (RPTN): Kepulauan Seribu Periode 2000-2015 (Buku I) Balai Taman Nasional Laut Kepulauan Seribu.

Seri Panduan Lapangan Burung-Burung di Sumatera, Jawa, Bali dan Kalimantan. Birdlife International-Indonesia Program-Pusat Penelitian dan Pengembangan Biologi LIPI, Cibinong. Muslim, I.A. dan Frans, S.J.E. (1994).

Sudaryanto. 1997. Keanekaragaman Burung di Kampus Udayana Badung Bali. Jurnal Ilmiah. Berkala Ilmiah. 